TUGAS PERBANDINGAN AGAMA

\title{
BERANI HIDUP MENDERITA SEBAGAI UNGKAPAN IMAN DALAM \\ PANDANGAN KITAB SUCI DAN ALQURAN
}

Dosen : Dr. Agustinus Wisnu Dewantara S.S., M.Hum

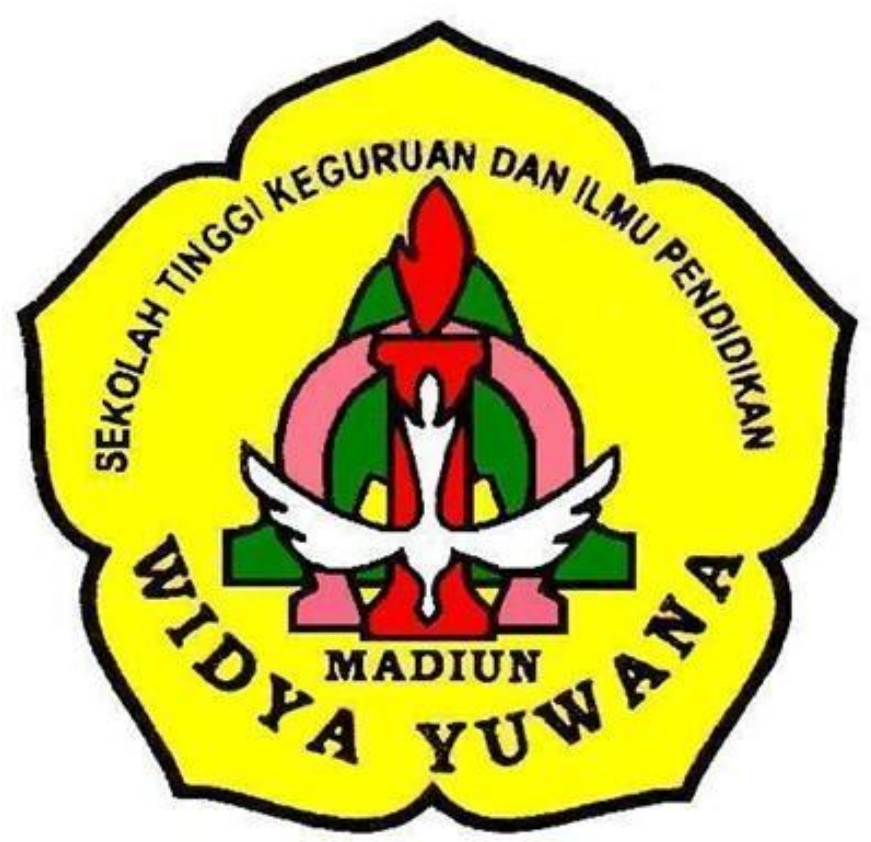

Oleh :

Hendisius Paulus

(152835)

SEKOLAH TINGGI KEGURUAN DAN ILMU PENDIDIKAN WIDYA YUWANA MADIUN

2019 


\section{BAB I \\ PENDAHULAN}

\section{Latar belakang}

Duka, derita, serta lara adalah pengalaman universal manusia yang tidak dapat dihindari. Penderitaan menjadi momok mengerikan dan menakutkan yang selalu membayangi dan mengancam kebahagiaan serta eksistensi kehidupan manusia (Hogan, 2002:7). Hal ini dapat dilihat dari usaha-usaha yang dilakukan manusia dengan sekuat tenaga dan daya untuk menghindari penderitaan (Marianto \& Suhendra, 1998:107).

Kita tahu bahwa naluri terdalam hidup manusia adalah memperoleh kebahagiaan dan keselamatan. Hal ini berarti semua jenis masalah yang bersifat menyakitkan, tidak menmbahagiakan, dan tidak menyenangkan seperti kejahatan dan penderitaan serta kesulitan lainnya dihindari bahkan disingkirkan. Namun, kenyataannya, kita sebagai manusia selalu harus berhadapan dengan masalah-masalah pahit dan getir serta tragis yang membuat manusia memberontak bahkan mengakhiri hidup dengan jalan pintas karena merasa hidup ini tak ada artinya lagi (Marianto \& Suhendra, 1998:14).

Di berbagai belahan dunia, tidak sedikit orang yang mengalami penderitaan dengan berbagai jenis dan penyebab yang meluluhlantakan hidup manusia (Hagon, 2002: 12). Bencana Tsunami yang menggoncang bumi Aceh dan Nias pada 26 Desember 2014 begitu dahsyat tentu saja menambah beban penderitaan manusia yang sudah ada. 


\section{BAB II \\ PEMBAHASAN}

\subsection{Penderitaan}

Penderitaan berasal dari kata derita, kata derita berasal dari bahasa sansekerta yakni dara yang berarti menahan atau menanggung. Berarti derita adalah menanggung atau merasakan sesuatu yang tidak menyenangkan.

Intensitas penderitaan memiliki tingkat, ada penderitaan yang berat serta ada pula yang ringan. Naum, penderitaan individu juga menentukan berat tidaknnya intensitas penderitaan, suatu peristiwa yang dianggap penderitaan oleh seorang, belum tentu merupakan penderitaan bagi orang lain. Dapat pula suatu penderitaan merupakan energi yang positif untuk seseorang bangkit, atau sebagai langkah awal untuk mencapai suatu kenikmatan dan kebahagiaan asalkan ia ikhlas dalam menjalani penderitaan tersebut. Wahyu Hidayatul Laili, (2017) Manusia dan penderitaan, http://wahyuhl.blogspot.com/2017/03/manusia-danpenderitaan_84.html, (diakses pada 19 juni 2019, pukul 21:20).

\subsection{Situasi manusia saat ini}

Berbicara tentang penderitaan, memang sesuatu yang tidak dapat dihindari, kita sebagai manusia harus bijak dalam menghadapinnya. Namun pada jaman sekarang orang berlomba-lomba untuk menghindari penderitaan tersebut, mulai dari yang bisa di cerna oleh logika sampai sesuatu yang tidak dapat ditangkap logika sekalipun. Tidak sedikit diantara kita melakukan hal apapun untuk menghindari penderitaan tersebut.

Melihat dari jenis-jenis penderitaan, saya ingin melihat situasi di indonesia bahwa para tokoh-tokoh kekuasa yang masih ada mengalami ketakutan, sehingga ketakutan itulah yang menimbulkan kerusakan. Takut akan kehilangan kekuasaan membuat mereka berani melakukan korupsi, takut akan tidak terwujudnya menjadi penguasa, sehingga melakukan jalan pintah apapun untuk menempuh supaya bisa berkuasa sekalipun jalan pintas itu tidak menghargai sesama manusia atau tidak lagi melihat martab sesama manusia dan takut akan momok kekuasaan menimbulkan laku korup pada diri mereka yang memndam perasaan takut itu.

Kita juga sering tidak menjadari bahwa beranda pada zona nyaman juga dapat membuat kita terlena dan keterlenaan itu bisa membawa kita padapenderitaan. Penderitaan bukan hanya yang datang dari peristiwa alam, tetapi penderitaan lebih banyak datang dari diri sendiri yang seringkali karena salah mengambil keputusan. 


\subsection{Penderitaan menurut pandangan Kitab suci katolik (Kisah Ayub)}

Di lihat dari sudut teologi, persoalan sudah teodise sudah dibuka ketika kita membaca penderitaan yang dialami oleh seorang yang saleh. Orang tersebut adalah Ayub. Ayub berseru, "Aku telah bosan hidup, aku berseru minta tolong kepada kepada-Mu, tetapi Engkau tidak menjawab; aku berdiri menanti, tetapi Engkau tidak menghiraukan aku. Anak panah dari Yang maha kuasa tertancap dalam tubuhku, semuanya itu sama saja, itulah sebabnya aku berkata: Yang tidak bersalah dan yang bersalah kedua-duanya dibinasakan-Nya" (Ayb. 10:1; 30:28; 6;4;9;22). Dari pernyataan Ayub tersebut semakin mempersulit kita untuk memahami bagaimana untuk menjelaskan menggapa Allah, yang diyakini mahakuasa dan mahakasih, serta mahaadil, mau membiarkan penderitaan yang teragis itu terjadi.

Dalam kitab suci penderitaan bukan hanya di ceritakan oelh kitab Ayub, akan tetapi kitab mazmur juga menggugat hal yang sama. Mazmur 73 secara jelas menggugat keilahian Allah berhadapan dengan kenyataan yang bertolak belakang dengan pengakuan iman akan Allah. Ini adalah pergumalan iman yang nyata. Penulis mazmur 22 dan 73 juga memunculkan satu pertanyaan, menggapa penderitaan datang kepadaorang-orang yang mencintai Tuhan? Menggapa kesulitan datang kepada orang-orang yang hatinya bersih? Nmenggapa sakitpenyakit justru datang kepadaorang-orang yang lebih mencintai dan mengasihi Tuhan? Menggapa kesusahan dan kemiskinan datang kepada anak-anak Tuhan? Menggapa hal-hal itu terjadi? Pertanyaan-pertanyaan itu merupakan menyatakan krisis iman yang diangkat oleh penulis Mazmur ini.

Ditinjau keseluruhan, Ayub mengalami penderitaan dari berbagai sisi kehidupan, di antaranya:

\subsubsection{Penderitaan secara jasmani}

Nilai kesehatan lebih tinggi dari kekayaan apapun yang ia miliki. Dengan kesehatan Ayub bisa kembali lagi bekerja dan melakukan seluruh aktivitas untuk meraih kembali keberhasilan yang pernah ia miliki. Namun apa daya kekuatan yang satu ini pun dirampas oleh iblis. Ayub tidak ada kemampuan untuk bekerja dan berkarya meraih penghasilan, sebab ia sangat lemah dan menderita karena penyakitnya, seperti ada tertulis, "kemudian iblis pergi kehadapan Tuhan, lalu ditimpanya Ayub dengan barah yang busuk dari telapak kakinya sampai ke batu kepalanya" (Ayb.2:7). Ayub juga mengalami penyakit gatal, "lalu Ayub menggambil sekeping beling untuk mengaruk-garuk badannya, sambil duduk ditengahtengah abu" (Ayb. 2:8) 


\subsubsection{Penderitaan secara Rohani}

Kekuatan terakhir Ayub yakni kerohaniannya, di mana Tuhan bersemayam di dalam jiwanya yang selama ini diajak dialog secara intim. Namun, kekuatan Ayub tidak mampu memberikan solusi yang berarti. Allah berdiam diri dan tidak memberikan reaksi sedikit pun. Allah baru turun disaat terakir Ayub mengalami ujiannya (Ayb. 38:1) hal yang memberiakn kekuatan dan semangat baru serta berkat bagi Ayub.

\subsubsection{Penderitaan secara Emosional}

Ayub sangat mengalami stres dalam menghadapi situasi ini, sebab dalam waktu singkat suasana kehidupannya berubah drastis. Kenikmatan fisiknya berubah menjadi kegetiran. Perasaan Ayub tercabik-cabik ketika melihat anaknya mati dan hatinya hancur pada saat ditinggalkan isterinya. Hal ini membuat Ayub bukan saja mengalami stres tetapi depresi berat sehingga ia mengutuki hari kelahirannya (Swindoll, 2004:76)

\subsubsection{Penderitaan secara Sosial}

Diakui bahwa masa-masa kejayaan Ayub membuatya menjadi orang terhormat dakalangan warganya. Namun setelah terjadi malapetaka, orang memandangnya dengan sebelah mata. Mereka menuduh ada kecurangan dan dosa sehingga Allah menimpakan berbagai macam malapetaka kepadannya. Masyarakat tidak lagi mendekati lagi seperti masamasa kejayaannya. Hal ini dilakukan sebab mereka tidak mau terkena tulah yang dialami oleh Ayub dengan bukti penyakit yang masih menempel di badannya (Ayb. 19:13-19)

\subsubsection{Penderitaan secara Ekonomi}

Keseluruhan kekayaan yang dikumpulkan Ayub bertahun-tahun musnah di rampas oleh iblis. Dari bencana sebagi bukti bahwa kekayaan Ayub dirampas oleh iblis dalam waktu yang singkat. Allah juga membiarkan iblis merampas harta dan kekayaan Ayub secara tidak ada belaskasihan (Swindoll, 2004:35).

Dalam asyiknya, iblis bukan saja merampas, tetapi juga membunuh para penjagannya (Ayb. 1:15). Selanjutnya orang-orang kasdim merampok untannya dan membunuh para pelayannya (Ayb. 1:17).

\subsubsection{Penderitaan dalam rumah tangga}

Keharmonisan rumah tangga Ayub hancur dalam waktu singkat. Tercatat dengan jelas bahwa anak-anak Ayub dalam waktu yang singkat dibantai iblis dengan cara mendatangkan angin ribut yang merobohkan rumah yang menimpa anak-anaknya (Ayb. 1: 18-19). Istri Ayub yang semula tak pernah berbuat kesalahan dan dosa, akhirnya jatuh dalam dosa. Hal ini terlihat dari ucapannya yang menyuruh suaminya untuk mengutuk Allah (Ayb. 2:9-10) dari hal inilah keluarga Ayub kehilangan keharmonisan. 


\section{Penderitaan menurut pandangan alquran}

Sebuah penderitaan dalam pandangan islam disebabkan oleh dua kemungkinan, pertama merupakan ujian dari Allah dan kedua karena azab atau siksaan dari Allah.

Allah berfirman dalam al quran surat Al Baqoroh ayat; 155 yang artinya:

"Sunggguh akan kami berikan cobaan kepadamu dengan sedikit ketakutan, kelaparan, kekurangan harta, jiwa dan buah - buahan".

Allah juga berfirman dalam surat Ar Rum ayat: 41, yang artinya:

"Telah timbul kerusakan di darat dan di laut, disebabkan ulah tangan manusia, karena Tuhan hendak merasakan kepada mereka sebagian dari akibat perbuatan mereka, supaya mereka kembali kepada kebenaran".

Untuk itu manusia diseru untuk selalu

Sakit merupakan salah satu dari sebuah penderitaan, dalam buku panduan menghadapi sakit dan kematian karya Ahmad Yani, disebutkan terdapat lima keutamaan sakit menurut islam.

\subsection{Mengahapus dosa}

Dengan penyakit yang diderita oleh seorang muslim, dosa yang pernah dilakukannya bisa terhapus karena penderitaannya dalam menghadapi penyakit menjadi kafarat atau penebus dosanya, Rasullulah bersabda: "Tiada seorang mukmin yang rasa sakit, kelelahan (kepayahan), diserang penyakit atau kesedihan(kesusahan) sampai duri yang menusuk (tubuhnya) kecuali dengan itu Allah menghapus dosa - dosanya" (HR Bukhori).

$\checkmark$ Tetap mendapat pahala dari amal kebaikan yang biasa dilakukannya diwaktu sehat Hal ini karena ia tidak bisa menjalankan amal kebaikan itu bukan karena ia tidak mau, tetapi karena ia dalam keadaan sakit. Misalnya seseorang yang setiap harinya selalu sholat berjamaah di masjid, setiap langkahnya diangkat baginya satu derajat dan dihapuskan satu kesalahannyakemmudian malaikat akan terus mengucapkan sholawat (memintakan ampunan) kepadanya, selama dia masih berada di ruangan sholat tersebut, maka ketika orang tersebut sakit ia masih tetap mendapat pahalanya. Rasulullah Saw bersabda: “ apabila salah seorang hamba sakit atau bepergian ( safar ), maka Allah mencatat pahalanya seperti pahala amal yang dikerjakannya sewaktu ia tidak bepergian atau sehat." (HR. Bukhori).

Rasulullah juga bersabda: “ Apabila seorang hamba sakit sedang ia biasa melakukan suatu kebaikan, maka Allah berfirman kepada malaikat: catatlah bagi hambaKu pahala seperti yang biasa dilakukan ketika sehat.”(HR Abu Hanifah). 
$\checkmark$ Memperoleh pahala kebaikan

Seorang muslim yang sabar dalam menghadapi penyakit yang dideritanya maka baginya pahala. Rasulullah Saw bersabda: “Barang siapa dikehendaki oleh Allah kebaikan baginya, maka dia ( diuji ) dengan suatu musibah.” ( HR. Bukhori ).

$\checkmark$ Memperoleh derajat yang tinggi disisi Allah

Hal ini karena di surga ada derajat tertentu yang harus dicapai, bila seorang muslim tidak mampu mencapainya dengan suatu amal, maka ia bis amemperolah derajat yang tinggi dengan musibah atau penyakit yang dideritanya, Rasulullah Saw bersabda: "Wabah adalah syahadah ( mati syahid ) bagi setiap muslim.” ( HR. Bukhori ).

Rasulullah Saw juga bersabda: "Seorang hamba memiliki suatu derajat di surga, katika ia tidak dapat mencapainya dengan amal - amal kebaikannya, maka Allah menguji dna mencobanya agar ia dapat mencapai derajat itu.” (HR. Thabrani ).

$\checkmark$ Memperoleh ganjaran berupa surga

Rasulullah bersabda: “ Apabila Aku menguji hambaKu dengan membutakan kedua matanya dan dia bersabar, maka Aku ganti kedua matanya itu dengan surga." (HR. Ahmad).

Mmeskipun penyakit itu tidak menyenangkan namun sakit merupakan ujian yang dapat memberikan keutamaan dan manfaat yang besar, untuk itu penyakit harus dihadapi dengan sikap, pemikiran dan perilaku yang positif agar hal positif tersebut akan datang kepada kita.

\section{$\checkmark$ Hikmah sakit}

Sakit merupakan kondisi yang tidak diinginkan oleh setiap orang, namun sakit kadang harus diterima sebagai takdir dan cobaan. Setiap muslim harus yakin bahwa yang menurunkan penyakit adalah Allah dan hanya Allah yang berkuasa menyembuhkan. Rasulullah Saw bersabda: “ Berobatlah, Allah tidak mengadakan penyakit melainkan Dia mengadakan pula obatnya, kecuali satu penyakit, sahabat bertanya: penyakit apakah ? Dijawab: penyakit karena tua.” ( HR. Ahmad).

"Setiap cobaan apa saja yang menimpa seorang muslim, sampai sebuah tusukan duri adalah karena salah satu dari dua sebab, yakni karena Allah hendak mengampuni kesalahannya yang tidak dapat diampuni melainkan dengan cobaan itu, atau Allah hendak memberi suatu kemuliaan yang tidak dapat dicapainya kecuali melalui cobaan itu." (HR. Ibnu Abi Dunya).

Saya juga pernah membaca sebuah buku yang berjudul "berani hidup siap mati" prinsip menjalani hidup dan menikmati hidup sehari-hari dengan spirit Allah. 
Kegagalan adalah keberhasilan yang tertunda, inilah kata-kata yang sangat tidak asing kita dengar. Kata-kata tersebut adalah ungkapan dari langkah-langkah seseorang yang menuju kesuksesan dan keberhasilan, tetapi kesuksesan itu tidak dapat dicapai dan justru kegagalan yang tertuai. Namun ada orang yang mau menerima kegagalan, tapi pada akhirnya ia lemah serta menyerah. Akan tetapi yang lain adapula menganggap bahwa kegaglan adalah motivasi dan sebagai sarana intropeksi diri, sehingga memberikan modal untuk membuat langkah-langkah baru dalam mencapi tujuan.

Kata menderita dalam Alquran berasal dari bentuk kata kerja dahulu syaqiya dan kata kerja kekinian yasyqa. Bentuk kata bendanya adalah /syaqawah, syaqan, syaqwah, dan syiqwah.

Terdapat pada Ensiklopedia Alquran terungkap seorang alim, Raghib al-Isfahani, yang mengartikan kata ini adalah lawan kata sa'adah (kebahagiaan). Sama halnya kebahagiaan, penderitaan juga bersifat sesuatu yang duniawi seperti keburukan atau penderitaan yang terjadi sekarang dan ukhrawi (yang bersifat akhirat).

Hal yang disampaikan yasyqa, yang terdapat di surah Thaha (20) ayat 2. "Ma anzalna 'alaikal qurana litasyqa, kami tidak menurunkan Alquran ini kepadamu agar kamu menjadi susah." Allah menurunkan Ayat ini sebagai jawaban kepada orang-orang musyrik yang berkata kepada Rasulullah, tatkala mereka melihat Rasul begitu tekun dan sungguh-sungguh dalam beribadah. "Hai Muhammad, sesungguhnya Alquran ini diturunkan kepadamu hanya untuk menyulitkanmu." Ayat itu sangat membuktikan bahwa Alquran tidak untuk menyulitkan orang. Hal ini sangat sama dijelaskan dalam surah al-A'raf [ $\left.{ }^{7}\right]$ ayat 2.

Hapsari Endah, (2017, 03 Maret). Bagaimana Alquran Memandang Penderitaan. Dikutip 21 Juni 2019 dari https://www.republika.co.id/berita/dunia-islam/fatwa/13/11/23/mwp0w8bagaimana-alquran-memandang-penderitaan 


\section{BAB III}

\section{PENUTUP}

\section{Kesimpulan}

Melihat dari alkitab dan alquran bahwa penderitaan dipandang sebagai sarana Allah menyampaikan kuasanya, Allah tidak bermaksud menghukum sekalipun orang saleh/soleh . sekarang kita dapat melihat bahwa hidup menderita bukanlah suatu yang harus terlalu ditakutkan.

Dalam perjanjian lama Ayub sebagai tokoh rang saleh yang mengalami penderitaan, akan tetapi dia menerima dengan ikhlas akan penderitaan itu. Begitu juga apa yang disampaikan didalam Alquran mengatakan bahwa penderitaan suatu proses yang harus kita jalani. Tidak semua orang yang mengalami penderitaan dapat menimbulkan dampak negatif bagi kehidupannya. Penderitaan hendaklah kita hadapi. Karena menghadapi penderitaan berati kita berserah pada Tuhan. Dampak negatif yang mungkin bisa saja muncul akibat penderitaan yaitu, berkurangnya gairah hidup, membatasi segala gerak hidup, kecewa, putus asa untuk melanjutkan hidup, dan lain sebagainya. Sedangkan dampak positifnya yaitu, sikap optimis untuk menjalani segala suka-duka kehidupan dengan sikap lapang dada. Sikap keras untuk melawan penderitaa, bahkan membantu seseorang untuk keluar dari penderitaan. 


\section{Daftar pustaka}

http://artikel.sabda.org/penderitaan

Wahyu, (2017) Manusia dan penderitaan, http://wahyuhl.blogspot.com/2017/03/manusia-danpenderitaan_84.html, (diakses pada 19 juni 2019, pukul 21:20).

Hapsari Endah, (2017, 03 Maret). Bagaimana Alquran Memandang Penderitaan. Dikutip 21 Juni 2019 dari https://www.republika.co.id/berita/dunia-islam/fatwa/13/11/23/mwp0w8bagaimana-alquran-memandang-penderitaan 